\title{
Research on Dynamic Monitoring and Ecological Restoration of Mining Environment in the Source Region of the Yellow River
}

\author{
Weiling Yao ${ }^{1, *}$, Wenjia $\mathrm{Xu}^{1}$, Jie Wang ${ }^{1}$, Hao Wang ${ }^{1}$, Xiaoyang $\mathrm{Liu}^{1}$, and Cunhao Jiang ${ }^{1}$ \\ ${ }^{1}$ China Aero Geophysical Survey and Remote Sensing Center for Natural Resources, 100083 Beijing, China
}

\begin{abstract}
The source region of the Yellow River is facing with problems of local ecosystem degradation and reduction of water conservation function, and the ecological environment in the source region of the Yellow River is fragile. Mining development is one of the key factors affecting the ecological environment in the source region of the Yellow River. Based on the high-resolution remote sensing satellite data of 2015 and 2018, this paper carried out the monitoring of the current situation and dynamic changes of the mine environment in the source region. The results show that the main mine environmental problems, caused by mining development, in the source region are land excavation and land occupation, and the growth rate is pretty fast. At present, the recovery rate of mines is low, only $25.24 \%$. According to the present situation of mining environment, regional physical geography and other factors, the mine damaged land in the source region of the Yellow River is divided into three types: the natural restoration areas, the general restoration areas and the key restoration areas. The ecological restoration of mines in the source region should adhere to the strategy of taking measures according to local conditions, and offer specific ecological restoration proposals for each type of areas. The ecological restoration of mines in the source region should focus on water conservation, strengthen the restoration of stocking mine damaged land, study the permitting mechanism of mining activities, and reinforce the function of regional ecological protection.
\end{abstract}

\section{Introduction}

The Yellow River is the most important birthplace of Chinese civilization. It plays a significant overall and strategic role in China's ecological security, economic and social development ${ }^{[1]}$. The Yellow River basin is well known as the "energy basin" [2], which is rich in coal, oil, natural gas and non-ferrous metals, with coal reserves account for more than half of the country, and it is a crucial energy, chemical, raw material and basic industrial base in China ${ }^{[3]}$. At present, there are a large amount of mines in the Yellow River basin, with a large area of land damaged and occupied by mining. The intensity of mining development activities is high, meanwhile, the impact on the ecological environment of the basin is arising.

For a long time, many scholars have carried out studies on the law of ecological environment evolution and development in the Yellow River basin from different perspectives, which have played an important role in promoting the protection and restoration of the ecological environment in the basin ${ }^{[4-6]}$. Most scholars use methods of remote sensing and GIS analysis to study the current situation and evolution law of the ecological environment of the basin from the perspective of macroscopic scale, or the spatial and temporal evolution of natural resource elements ${ }^{[7-10]}$. Some scholars also studied the ecological environment problems in the source area of the Yellow River from the perspectives of land desertification and salinization, and put forward some policy Suggestions ${ }^{[11-}$ ${ }^{13]}$. Look at previous research, scholars' research on the ecological environment in the source region of the Yellow River (hereinafter referred to as "the source region") is characterized by multi-scale and multi-technical methods, and has achieved remarkable results, which plays an important role in promoting the ecological environment protection in the Yellow River basin. However, there is still little research on the impact of mining on the ecological environment of the source region from the perspective of mining, especially on the changes of ecological environment and protection and restoration caused by mining on the micro scale in the basin by using high resolution remote sensing technology.

This paper uses the data of high resolution remote sensing satellite in 2015 and 2018 to monitor the current state and dynamic change of mine ecological environment in the source region. In view of the present situation of mine development and damaged land in the source region, considering the regional natural geography, precipitation and other factors, the mine damaged land in the source region is divided into various types of restoration areas. The measures and suggestions of mine ecological restoration are put forward to provide basic data and

\footnotetext{
* Corresponding author: prekestolen@126.com
} 
decision support for mine environmental protection and ecological restoration in the source region.

\section{Overview of the research area}

Originating from the Qinghai-Tibet plateau, the Yellow River flows through Qinghai, Sichuan, Gansu, Ningxia, Inner Mongolia, Shanxi, Shaanxi, Henan and Shandong provinces, with a total length of $5464 \mathrm{~km}^{[2]}$. The source region is located on the Qinghai-Tibet plateau of China, mainly in Qinghai province. The terrain belongs to the third ladder, higher altitude. The climate is mainly located in semi-arid and semi-humid areas.

The source region is the "water tower" of the whole Yellow River basin, with huge ecological and environmental benefits. The mine ecological restoration in the source region is of great practical significance for the sustainable development and ecological protection of the Yellow River Basin. The geographical location map of the study area is shown in figure 1 .

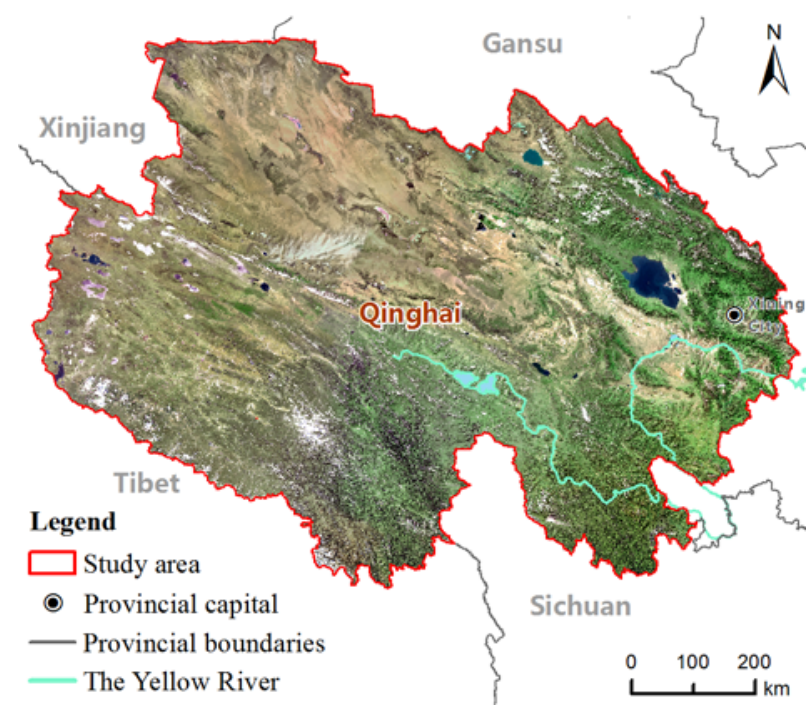

Fig. 1. Geographical location map of the study area

\section{Dynamic monitoring of mine environment}

\subsection{Data source}

Satellite data is the most important data used in this study. The satellite data sources are high-resolution remote sensing orthophoto images of the study area in 2015 and 2018. Satellite data types include ZY3, GF1, GF2, SPOT6, $\mathrm{BJ} 2$, Pleiades, etc. The resolution of remote sensing image is superior to or equal to 2.5 meters. The main satellite data parameters in study area is shown in table 1.

Among the data used to assist interpretation, the mining rights and the exploration rights are derived from the Information Center of the Ministry of Natural Resources. The basic data used for mine restoration division include the scope of national nature reserves, water systems at all levels, residential areas, highways, wetlands, railways and other transportation arteries.
Among them, the data of ecological function area, precipitation and transportation arteries are from the Data Center of Resources and Environmental Science of Chinese Academy of Sciences.

Table 1. Main satellite data parameters in study area

\begin{tabular}{|c|c|c|c|}
\hline \multirow{7}{*}{ GF2 } & \multirow{5}{*}{$\begin{array}{l}\text { Spectral } \\
\text { range }\end{array}$} & Panchromatic & $0.45 \sim 0.90 \mu \mathrm{m}$ \\
\hline & & \multirow{4}{*}{ multispectral } & $0.45 \sim 0.52 \mu \mathrm{m}$ \\
\hline & & & $0.52 \sim 0.59 \mu \mathrm{m}$ \\
\hline & & & $0.63 \sim 0.69 \mu \mathrm{m}$ \\
\hline & & & $0.77 \sim 0.89 \mu \mathrm{m}$ \\
\hline & \multirow{2}{*}{$\begin{array}{l}\text { Spatial } \\
\text { resolution }\end{array}$} & Panchromatic & $0.8 \mathrm{~m}$ \\
\hline & & multispectral & $3.2 \mathrm{~m}$ \\
\hline \multirow{7}{*}{$\mathrm{BJ} 2$} & \multirow{5}{*}{$\begin{array}{l}\text { Spectral } \\
\text { range }\end{array}$} & Panchromatic & $0.45 \sim 0.65 \mu \mathrm{m}$ \\
\hline & & \multirow{4}{*}{ Multispectral } & $0.44 \sim 0.51 \mu \mathrm{m}$ \\
\hline & & & $0.51 \sim 0.59 \mu \mathrm{m}$ \\
\hline & & & $0.60 \sim 0.67 \mu \mathrm{m}$ \\
\hline & & & $0.76 \sim 0.91 \mu \mathrm{m}$ \\
\hline & \multirow{2}{*}{$\begin{array}{l}\text { Spatial } \\
\text { resolution }\end{array}$} & Panchromatic & $0.8 \mathrm{~m}$ \\
\hline & & Multispectral & $3.2 \mathrm{~m}$ \\
\hline \multirow{16}{*}{ GF1 } & \multirow{6}{*}{$\begin{array}{l}\text { Spectral } \\
\text { range }\end{array}$} & \multicolumn{2}{|c|}{ High resolution camera } \\
\hline & & Panchromatic & $0.45 \sim 0.90 \mu \mathrm{m}$ \\
\hline & & \multirow{4}{*}{ Multispectral } & $0.45 \sim 0.52 \mu \mathrm{m}$ \\
\hline & & & $0.52 \sim 0.59 \mu \mathrm{m}$ \\
\hline & & & $0.63 \sim 0.69 \mu \mathrm{m}$ \\
\hline & & & $0.77 \sim 0.89 \mu \mathrm{m}$ \\
\hline & \multirow{2}{*}{$\begin{array}{c}\text { Spatial } \\
\text { resolution }\end{array}$} & Panchromatic & $2 \mathrm{~m}$ \\
\hline & & Multispectral & $8 \mathrm{~m}$ \\
\hline & \multirow{6}{*}{$\begin{array}{l}\text { Spectral } \\
\text { range }\end{array}$} & \multicolumn{2}{|c|}{ Wide camera } \\
\hline & & Panchromatic & \\
\hline & & \multirow{4}{*}{ Multispectral } & $0.45 \sim 0.52 \mu \mathrm{m}$ \\
\hline & & & $0.52 \sim 0.59 \mu \mathrm{m}$ \\
\hline & & & $0.63 \sim 0.69 \mu \mathrm{m}$ \\
\hline & & & $0.77 \sim 0.89 \mu \mathrm{m}$ \\
\hline & \multirow{2}{*}{$\begin{array}{l}\text { Spatial } \\
\text { resolution }\end{array}$} & Panchromatic & \\
\hline & & Multispectral & $16 \mathrm{~m}$ \\
\hline \multirow{6}{*}{ ZY3-01 } & \multirow{5}{*}{$\begin{array}{l}\text { Spectral } \\
\text { range }\end{array}$} & Panchromatic & $0.50 \sim 0.80 \mu \mathrm{m}$ \\
\hline & & \multirow{4}{*}{ Multispectral } & $0.45 \sim 0.52 \mu \mathrm{m}$ \\
\hline & & & $0.52 \sim 0.59 \mu \mathrm{m}$ \\
\hline & & & $0.63 \sim 0.69 \mu \mathrm{m}$ \\
\hline & & & $0.77 \sim 0.89 \mu \mathrm{m}$ \\
\hline & $\begin{array}{c}\text { Spatial } \\
\text { resolution }\end{array}$ & $\begin{array}{r}\text { Metacl } \\
\text { Panchrom }\end{array}$ & $\begin{array}{l}\text { matic } \\
\text { ic: } 2.1 \mathrm{~m}\end{array}$ \\
\hline
\end{tabular}




\begin{tabular}{|c|c|c|c|}
\hline & & \multicolumn{2}{|c|}{$\begin{array}{c}\text { Front and rear } 22^{\circ} \\
\text { Panchromatic: } 3.5 \mathrm{~m}\end{array}$} \\
\hline & & \multicolumn{2}{|c|}{ Elevation Multispectral: $5.8 \mathrm{~m}$} \\
\hline \multirow{7}{*}{ Spot-6 } & \multirow{5}{*}{$\begin{array}{l}\text { Spectral } \\
\text { range }\end{array}$} & Panchromatic & $0.45 \sim 0.75 \mu \mathrm{m}$ \\
\hline & & \multirow{4}{*}{ Multispectral } & $0.45 \sim 0.52 \mu \mathrm{m}$ \\
\hline & & & $0.53 \sim 0.59 \mu \mathrm{m}$ \\
\hline & & & $0.62 \sim 0.69 \mu \mathrm{m}$ \\
\hline & & & $0.76 \sim 0.89 \mu \mathrm{m}$ \\
\hline & \multirow{2}{*}{$\begin{array}{l}\text { Spatial } \\
\text { resolution }\end{array}$} & Panchromatic & $1.5 \mathrm{~m}$ \\
\hline & & Multispectral & $6 \mathrm{~m}$ \\
\hline \multirow{7}{*}{$\begin{array}{l}\text { Pleiades- } \\
\text { 1B }\end{array}$} & \multirow{5}{*}{$\begin{array}{l}\text { Spectral } \\
\text { range }\end{array}$} & Panchromatic & $0.47 \sim 0.83 \mu \mathrm{m}$ \\
\hline & & \multirow{4}{*}{ Multispectral } & $0.43 \sim 0.55 \mu \mathrm{m}$ \\
\hline & & & $0.50 \sim 0.62 \mu \mathrm{m}$ \\
\hline & & & $0.59 \sim 0.71 \mu \mathrm{m}$ \\
\hline & & & $0.74 \sim 0.94 \mu \mathrm{m}$ \\
\hline & \multirow{2}{*}{$\begin{array}{l}\text { Spatial } \\
\text { resolution }\end{array}$} & Panchromatic & $0.5 \mathrm{~m}$ \\
\hline & & Multispectral & $2 \mathrm{~m}$ \\
\hline
\end{tabular}

\subsection{Research methods}

The remote sensing survey and monitoring of the current situation and dynamic changes of mine environment in the source region are carried out by means of the combination of remote sensing and multi-source data, computer information extraction and human-computer interaction interpretation, indoor interpretation and field verification. The workflow is shown in figure 2.

First, collect and analyse all kinds of basic data in the study area. Second, reasonably select high-resolution remote sensing data. By using image correction, image enhancement, image fusion and other methods to process image and establish interpretation signs. The ArcGIS software is used as the main platform for information extraction, which is stored in vector format and attributes the extracted spots. A minimum map spots area of $4 \mathrm{~mm}^{2}$ is needed to extract. Third, modify the wrong spots and supplement the missing spots through comprehensive analysis and field verification, quality control and inspection. During the field verification, the method of combining points, lines and faces is adopted to carry out field investigation on the map spots that need to be verified.

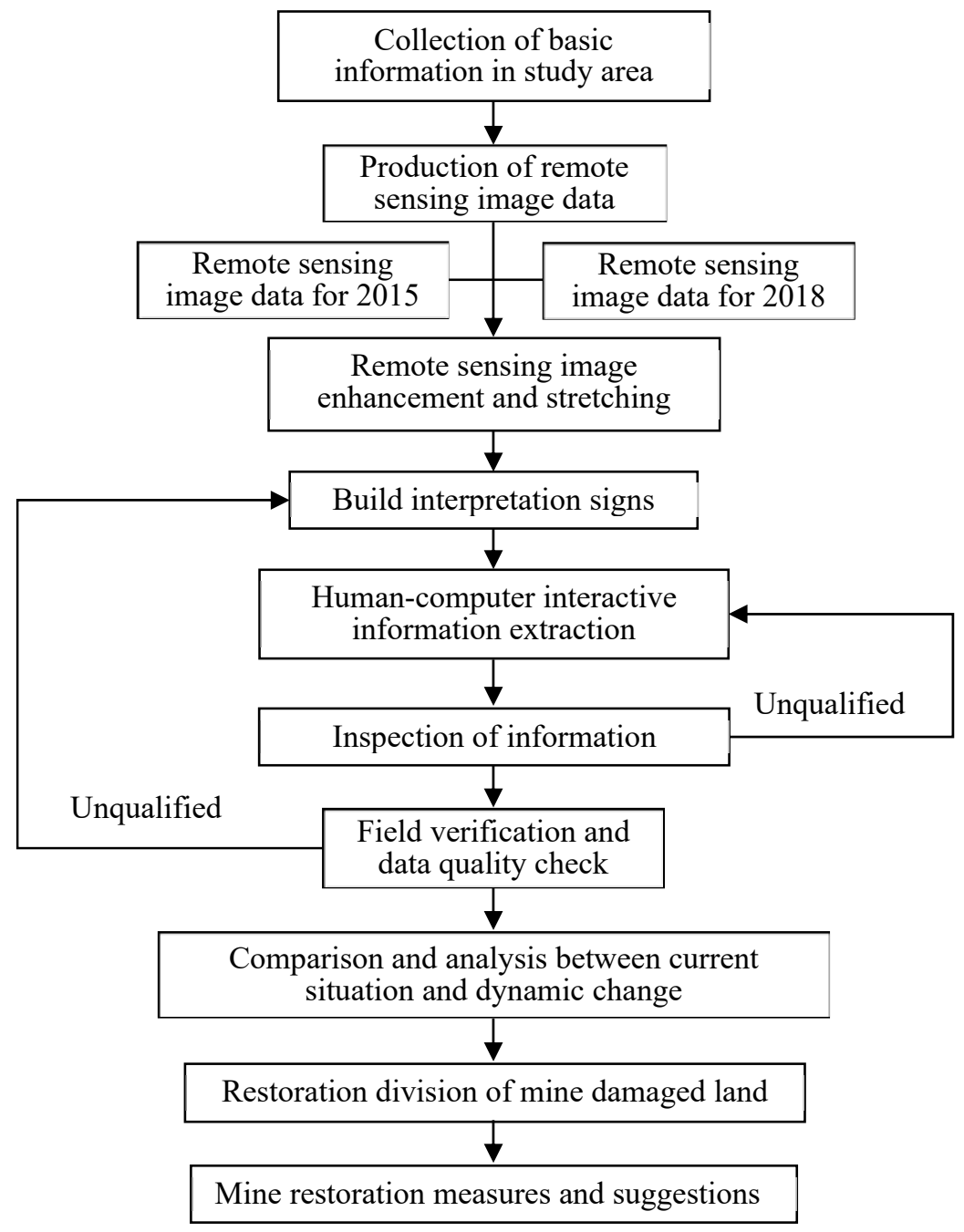

Fig. 2. Workflow for dynamic monitoring of mine environment in the source region 
Finally, according to the results of remote sensing monitoring, the mine damaged land in the source region is divided into different restoration areas, and the remediation measures are proposed for each type of restoration areas.

\subsection{Monitoring factors of mine environment}

According to the classification of damaged land in various mines, the monitoring factors of mine environmental information include stope face, transit site (such as coal storage yard, ore pile, coal cleaning plant, mineral processing plant), solid waste (such as soil dump, tailings pond, coal gangue, spoil bank), mine building (such as production area, office area, living quarters), etc ${ }^{[14]}$.
It is necessary to judge the attributes of all types of map spots, such as mineral species, mining status and type of damaged land when extracting map spots. In addition, we also need to monitor situation of mine environmental restoration, such as land use type after mine restoration.

Remote sensing monitoring of mine environment has a wide range of minerals, such as energy minerals, ferrous minerals, nonferrous minerals, precious metal minerals, metallurgical auxiliary raw materials of non-metallic minerals, chemical raw materials of non-metallic minerals, special non-metallic minerals, building materials and other non-metallic minerals. As shown in figure $3, \mathrm{a}, \mathrm{b}$ and $\mathrm{c}$ respectively represent the characteristics of remote sensing image of damaged land and mine restoration in energy, metal and non-metal mines in the study area.
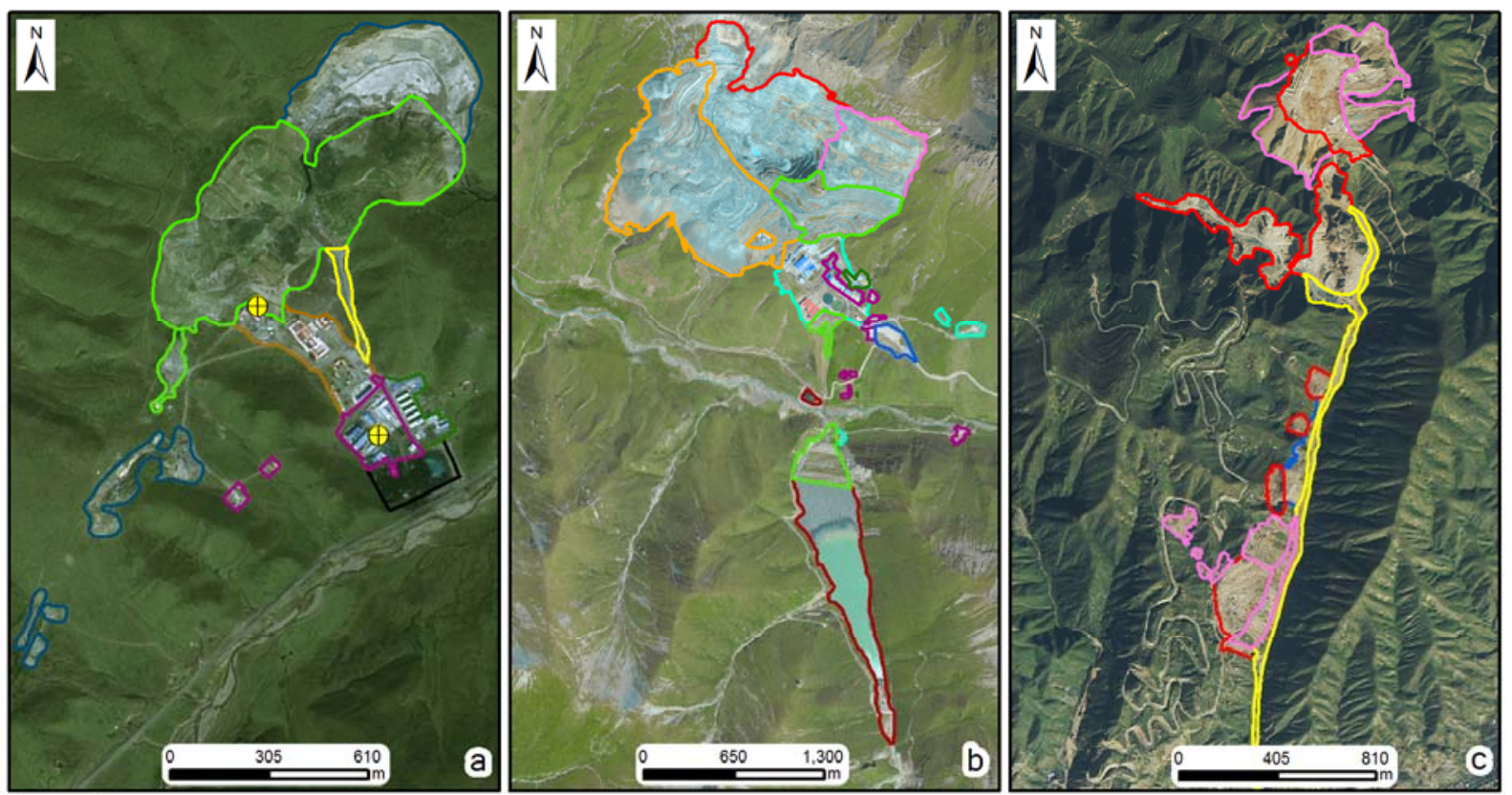

Legend
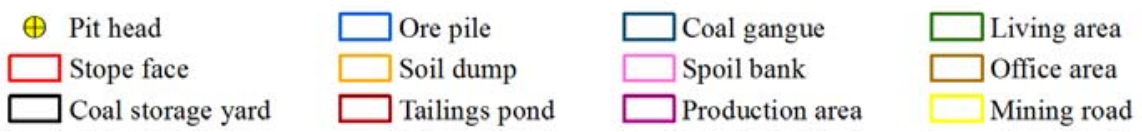

Mine recovery

Mineral processing plant

Fig. 3. Interpretation signs of mine damaged land and restoration in study area

\section{Results and analysis}

\subsection{The Status of mine damaged land}

By 2018, the area of mine damaged land in the source region (mainly solid mines, not containing lake salt, water vapor or other minerals) was about 28,000 hectares. The area of damaged land caused by stope face, transfer site, solid waste and mine building accounted for $47.71 \%$, $17.00 \%, 29.33 \%$ and $5.96 \%$ respectively, taking stope face as the top. It can be seen from table 2 that the damaged land of stope face and transfer site is mainly composed of building materials and other non-metals. The land area damaged by solid wastes and mine buildings is mostly energy and mineral. The mining methods are usually divided into three types: open pit, underground and joint mining. As of 2018, the area of mine damaged land in the source region was 21,419.29 hectares, 2,062.4 hectares and 4444.12 hectares under the three mining methods of open pit, underground and joint mining, accounting for $76.70 \%, 7.39 \%$ and $15.91 \%$ respectively. 
Table 2. Statistics on mine damaged land in the source region in 2015 and 2018 (in hectares)

\begin{tabular}{ccccccccc}
\hline \multirow{2}{*}{ Minerals } & \multicolumn{2}{c}{ Stope face } & \multicolumn{2}{c}{ Transit site } & \multicolumn{2}{c}{ Solid waste } & \multicolumn{2}{c}{ Mine building } \\
\cline { 2 - 9 } & $\mathbf{2 0 1 5}$ & $\mathbf{2 0 1 8}$ & $\mathbf{2 0 1 5}$ & $\mathbf{2 0 1 8}$ & $\mathbf{2 0 1 5}$ & $\mathbf{2 0 1 8}$ & $\mathbf{2 0 1 5}$ & $\mathbf{2 0 1 8}$ \\
\hline Energy minerals & 2208.03 & 2845.68 & 1303.84 & 837.4 & 2267.59 & 3921.38 & 407.82 & 754.71 \\
\hline Ferrous minerals & 88.84 & 190.17 & 105.37 & 293.38 & 435.96 & 743.94 & 31.94 & 161.53 \\
\hline Nonferrous minerals & 136.78 & 180.07 & 183.55 & 495.63 & 704.78 & 1217.23 & 162.37 & 184.71 \\
\hline Precious metal minerals & 195.39 & 705.74 & 120.14 & 313.21 & 581.83 & 528.35 & 33.98 & 58.8 \\
\hline $\begin{array}{c}\text { Metallurgical auxiliary } \\
\text { raw materials of non- } \\
\text { metallic minerals }\end{array}$ & 18.81 & 84.26 & 10.74 & 27.12 & 22.02 & 61.52 & 0.28 & 1.51 \\
\hline $\begin{array}{c}\text { Chemical raw materials } \\
\text { of non-metallic minerals }\end{array}$ & & 13.3 & 0.41 & 0.17 & 0.25 & 6.68 & & 0.97 \\
\hline $\begin{array}{c}\text { Special non-metallic } \\
\text { minerals }\end{array}$ & 9.51 & & & & & & \\
\hline $\begin{array}{c}\text { Building materials and } \\
\text { other non-metallic } \\
\text { minerals }\end{array}$ & 2906.01 & 9294.08 & 3121.21 & 2781.31 & 1790.93 & 1710.27 & 258.37 & 503.18 \\
\hline \begin{tabular}{c} 
Total \\
\cline { 2 - 8 }
\end{tabular} & 5553.86 & 13322.81 & 4845.26 & 4748.22 & 5803.36 & 8189.37 & 894.76 & 1665.41 \\
\hline
\end{tabular}

\subsection{Dynamic monitoring results of mine damaged land}

The analysis of dynamic monitoring results shows that from 2015 to 2018, the area of mine damaged land in the source region increased by 10828.57 hectares, with an average annual increase of $17.77 \%$. Among them, the average annual growth rate of land excavation was $33.86 \%$, and the annual growth rate of land occupied was $8.15 \%$. The area of damaged land, caused by stope face, solid waste and mine building, increased greatly, while the area of transit site decreased slightly. Among all minerals, the increase of damaged land area in building materials and other non-metal and energy mines was large, with an average annual growth rate of $20.95 \%$ and $10.55 \%$, respectively, while the growth rate increase of other minerals was small.

The number of mine damaged land in national nature reserves, key ecological function zones, wetlands and desertification areas has increased. Among them, the proportion of mine damaged land in desertification areas increases the most, and mine damaged land in national nature reserves increases the least, indicating that mining development activities in desertification areas increases obviously, yet the mining development supervision and environmental protection in nature reserves are relatively strong, as detailed in figure 4.

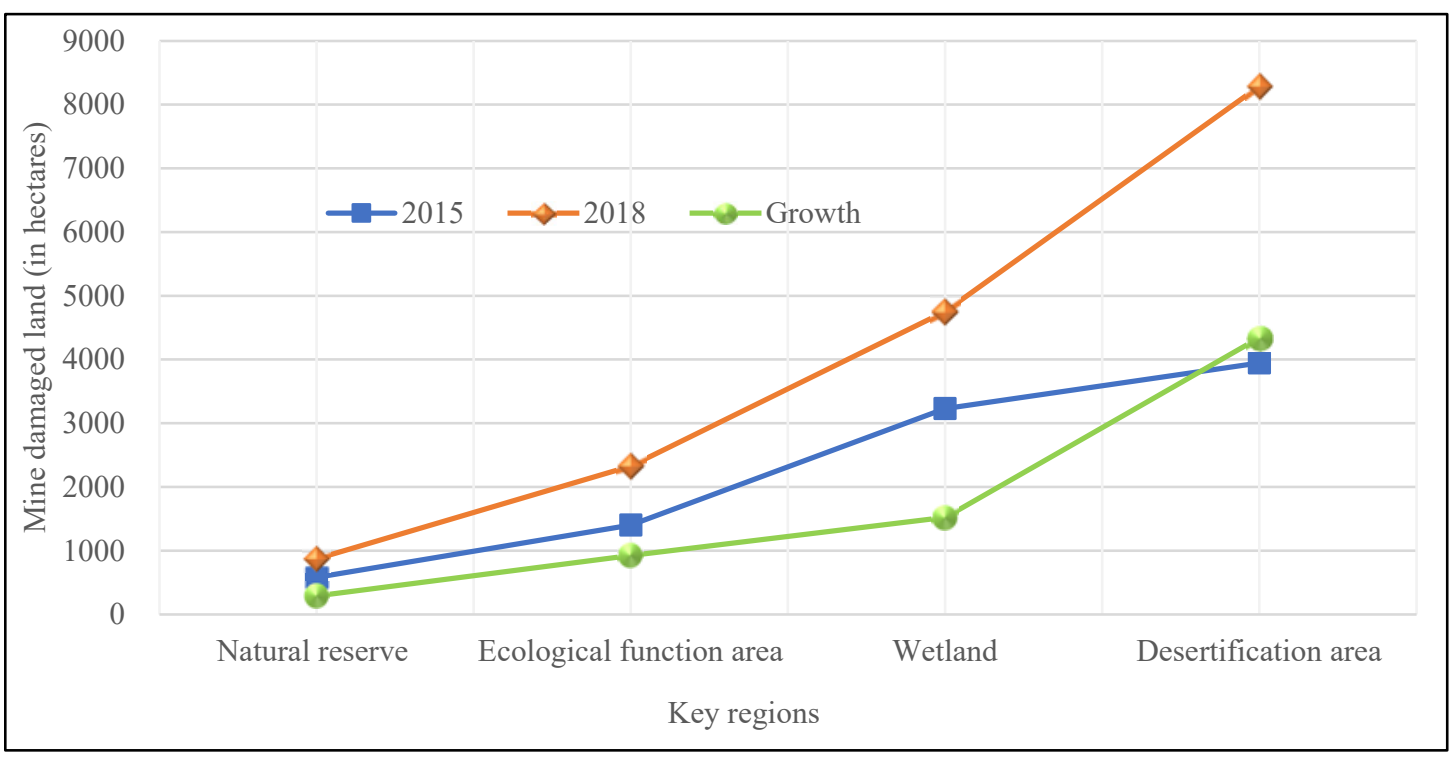

Fig. 4. Area change of mine damaged land in key regions from 2015 to 2018 


\subsection{The status of mine environmental restoration}

Monitoring results shows that the area of mine restoration in the source region is about 9,429.46 hectares. Solid waste occupies the largest area of land restoration, while the area of mine building restoration is the smallest. Grassland was the main type of land use type after restoration, accounting for $61.31 \%$ of the total area of restoration. The types of land use after restoration of damaged land in stope face, transit site, solid waste and mine building are detailed in Table 3 .

Table 3. Status of mine environmental restoration in the source region in 2018 (in hectares)

\begin{tabular}{ccccc}
\hline \multirow{2}{*}{$\begin{array}{c}\text { Types of land use after } \\
\text { restoration }\end{array}$} & \multicolumn{4}{c}{ Ways of damaged land in mines } \\
\cline { 2 - 5 } & Stope face & Transit site & Solid waste & Mine building \\
\hline Grass & 4564.77 & 115.91 & 1072.9 & 27.34 \\
\hline Arable land & 341.02 & 65.37 & 6.58 & 0.06 \\
\hline Land for mining or storage & 30.79 & 54.14 & & 1.49 \\
\hline $\begin{array}{c}\text { Public administration and public } \\
\text { service land }\end{array}$ & 75.48 & 17.02 & 22.2 & \\
\hline Transportation land & 4.69 & 0.4 & & 3.36 \\
\hline woodland & 64.7 & 3.8 & 327.35 & \\
\hline Other land & 1558.99 & 337.79 & 0.65 & 0.23 \\
\hline $\begin{array}{c}\text { Water area and land for water } \\
\text { conservancy facilities }\end{array}$ & 675.9 & 15.77 & 2.27 & 32.49 \\
\hline Residential land & 24.86 & 13.62 & 1431.95 & \\
\hline Total & 7341.2 & 623.82 & &
\end{tabular}

From the point of view of mine restoration, the mine management in the source region is dominated by treatment projects, accounting for more than $85 \%$. From the perspective of mining, the restoration area of sand, building sand, coal, brick and tile clay mines is relatively large. By 2018, the restoration rate of mines (equal to the restoration area divided by the total area of mine land) in the source region was about $25.24 \%$, indicating that the overall mine restoration rate is low and restoration measures need to be reinforced.

\subsection{Major mine environment problems}

From the previous analysis, it can be seen that there are mainly three types of mine environmental problems in the source region. Firstly, the surface landscape damage and soil erosion are directly caused by land excavated and damaged. Secondly, mine solid waste occupies land, which is easier to cause soil water pollution while changing land use function. Thirdly, the rate of mine environmental restoration is pretty low, and the topographical and geomorphic landscapes are seriously damaged in some areas, so it is difficult to repair. The efforts of mine environmental restoration should be strengthened.

\section{Ecological restoration of mine damaged land}

\subsection{Ecological restoration division}

The ecological restoration of mine damaged land is of great practical significance for the sustainable economic development and ecological protection of energy mines in the source region. According to the present situation of mine environmental problems, all mine damaged land spots in the source region are divided into natural restoration areas, general restoration areas and key restoration areas, and the division basis and results of various restoration areas are detailed in Table 4.

Table 4. Basis and results of ecological restoration division of mine damaged land (in hectares)

\begin{tabular}{clcc}
\hline Division type & \multicolumn{1}{c}{ Main division basis } & Divisional area & Percentage \\
\hline & $\begin{array}{l}\text { a) It is far away from the buffer zone of the main stream } \\
\text { and tributaries of the Yellow River. } \\
\text { b) Outside the sensitive areas of human activities, it is } \\
\text { Natural }\end{array}$ & $\begin{array}{l}\text { located in humid or sub-humid areas, and the ecological } \\
\text { background is easy to recover naturally. } \\
\text { c) Other spots that cannot be recovered naturally but also } \\
\text { do not need special manual intervention at the present }\end{array}$ & 7544.74 \\
\hline
\end{tabular}




\begin{tabular}{ll}
\hline & stage, such as those in remote deserts and mountainous \\
areas. \\
a) Within $15 \mathrm{~km}$ of the provincial capital city. \\
b) Prefecture-level city within $10 \mathrm{~km}$ around the city. \\
c) Within $5 \mathrm{~km}$ of county-level city. \\
d) Within $1 \mathrm{~km}$ around the town. \\
e) Within $10 \mathrm{~km}$ on both sides of tributaries of the Yellow \\
River. \\
f) Within $1 \mathrm{~km}$ on both sides of the road, expressway and \\
railway at or above the provincial level. \\
g) Within the scope of cultivated land. \\
h) Ancillary equipment in transit for mineral exploitation, \\
such as mine building and concentrator, cannot be restored \\
naturally, and manual dismantling or other simple treatment \\
measures shall be carried out.
\end{tabular}

Combined with the regional natural ecological conditions, the current situation of mine environment and the classification results of ecological restoration spots, this paper puts forward some targeted restoration measures and suggestions for regional mine ecological restoration.

\subsection{Natural restoration area}

The total area of mine damaged land in the natural restoration area is 7,544.74 hectares, which is mostly distributed in the semi-arid northern area and the semihumid southern area of the Qinghai-Tibet Plateau. For the abandoned mine stope face, solid waste and subsidence land in the desert arid and semi-arid areas in the north, after removing the mine facilities, the land can be simply recovered, and under the action of wind erosion and sand cover, it can be naturally restored to the original landform as far as possible. The semi-humid area in the southern part of the Qinghai-Tibet Plateau, far away from the human settlements and natural ecological functional areas, can be naturally restored to grassland and wasteland under the condition of confirming that the soil conditions are better. In addition, the mine in production should be strictly in accordance with the requirements of the mine development and utilization plan, soil and water conservation plan, and should carry out restoration during their production.

\subsection{General restoration areas}

The total area of mine damaged land in the general restoration area is 11330.94 hectares, and the targeted restoration measures are as follows:

\subsubsection{Tributaries of the Yellow River}

Within $10 \mathrm{~km}$ on both sides of the tributaries of the Yellow River also belongs to the key areas of soil and water conservation and landscape restoration. It mainly carries out soil restoration in abandoned mines, grass and vegetation restoration, and the construction of irrigation systems, etc., so as to reduce land damage caused by mining excavation and stacking of wastes, reduce soil erosion and beautify the ecological environment.

\subsubsection{Surrounding the human settlements}

The key points of mine restoration surrounding the human settlements are to eliminate the potential disaster, change the way of land use and beautify the ecological environment. For the coal mine area around the town, it is necessary to eliminate the collapse disaster. For abandoned mining land, it can be converted into other industrial uses or urban homestead according to local conditions, and can also be harnessing and used as mine park, urban green space, etc., to beautify the living environment of urban residents.

\subsubsection{Around the main traffic line}

In the visible range of sight on both sides of roads, highway and railway above the provincial level, the main means of restoration should be taken to beautify the landscape and eliminate disasters. Relevant areas should prevent and control the landslide and collapse caused by mining around the main traffic line and reduce the potential hazard. Through planting grass, planting trees and other green means to eliminate mining excavation damage, waste residue stacking caused by landscape damage.

\subsection{Key restoration areas}

The total area of mine damaged land in the key restoration area is 9050.13 hectares, and the corresponding restoration measures are as follows:

\subsubsection{Within the scope of nature reserves, ecological functional areas and wetlands}

It is suggested to focus on the important water conservation areas such as Sanjiangyuan and Qilian 
Mountains, and all mining enterprises in the scope of nature reserves, ecological functional areas and wetlands should be phased out. It is necessary to formulate and implement a policy for the liquidation of mining enterprises. Soil reconstruction, vegetation restoration, wetland reconstruction and landscape restoration are the key points for the development of damaged land in closed or abandoned mines. In addition, the department concerned should repair the river bed damage caused by sand mining and gold mining, and maintain the stability of various functional areas.

\subsubsection{Within $15 \mathrm{~km}$ of the main Yellow River}

The abandoned mines within $15 \mathrm{~km}$ of the main stream of the Yellow River are the vital points of control. For one thing, It is necessary to carry out soil pollution investigation on the damaged land developed by coal and metal mines on both sides of the Yellow River, especially on the river pollution caused by the tailings reservoir. For another, the land with better farming conditions, based on the completion of soil pollution investigation or remediation work, should be given priority to reclamation, followed by planting grass, shrub and other plants, and reduce soil erosion. Furthermore, relevant institutions need to formulate policies and measures for small mines that are under exploitation, and carry out rehabilitation and rectification after closure. It is vital to order the compulsory closure and rehabilitation of illegal mines. The last but not the least, for other mining enterprises that are temporarily unsuitable for closure, it is strictly required to produce in accordance with the green mining standards, and control the growth rate of damaged land while still mining.

\section{Conclusions}

Based on the analysis above, the following conclusions can be drawn:

Multi-source and high-resolution remote sensing image, integrated with application of GIS, can effectively monitor the dynamic changes of mine environment. Highresolution remote sensing image has played a vital role in the dynamic monitoring of mine environment, which can accurately reflect the situation of damaged land and mine restoration. The higher the resolution of remote sensing image is, the better the identification of mine features will be.

The main mine environmental problems in the source region of the Yellow River are land damage and land occupation, the destruction of surface landscape, soil erosion, soil or water pollution caused by mining activities. From 2015 to 2018, the number of mine damaged land in the source region of the Yellow River has increased, mainly in open-pit energy mines and nonmetal mines. At present, the rate of mine restoration is on the low side, and the mine restoration efforts need to be strengthened. It is also shown that the growth of mine damaged land in desertification area is obvious, while the area of mine damaged land in the nature reserve has little change, indicating that the mining development supervision and environmental protection in the nature reserve are better.

Water conservation should be the main goal in the ecological restoration of mines in the source region of the Yellow River, the ecological restoration efforts should adhere to strengthen the recovery rate of mine damaged land, and enhance the function of regional ecological protection.

Different restoration methods should be carried out for different areas. First, the natural restoration areas should be based on natural recovery and strictly prevent the destruction again. Second, multiple restoration methods should be taken for general restoration areas, such as ground disaster management, vegetation regreening and land reclamation. Third, it is vital that focus on strengthening nature reserves and supervising mining activities in the key restoration areas. Finally, we need to study the permitting mechanism for mining development further, to prevent and control source damage and pollution. The mining enterprises which can't exit temporarily should carry out the development treatment strictly while producing, according to the green mine law and standard.

\section{Acknowledgement}

This paper is co-funded by the geological survey project (No.DD20190705, No.DD20190511) of the China Geological Survey Bureau. Special thanks to experts such as Jinzhong Yang, Hongfeng Nie, Xiaoli Ge, Yanzuo Wang and Xianhua Yang for their guidance and help, thanks to the paper editors and anonymous reviewers.

\section{References}

1. WANG $\mathrm{Z}$ H. Strengthening the ecological environment governance in the Yellow River Basin. The People's Congress of China. 1, 47-48(2018)

2. XI J P. Speech at the symposium on ecological protection and quality development in the Yellow River Basin. Qiu Shi. 20, 1-5(2019)

3. Jin F J. Coordinated promotion strategy of ecological protection and high-quality development in the Yellow River Basin. Reform. 11, 33-39(2019)

4. QU C, ZHANG C L, WANG L Y, YUE B J, and LIU $\mathrm{X}$ Y. Application of high resolution remote sensing technology in dynamic monitoring of soil and water loss in Yellow River Basin. Bulletin of Soil and Water Conservation. 38, 1, 117-120(2018)

5. Ma L, Tian H Z and KANG L. Eco-environmental impact and spatial control of mineral resources exploitation in the Yellow River Basin. Resources Science. 42, 1, 137-149(2020)

6. ZHENG X K, CUI C Y and CUI Z H. Impact of sand excavation in river courses of the main Yellow river on ecological environment and countermeasures. Yellow River. 38, 1, 42-44(2016)

7. LI F X, Fu Y, LI L, Xiao J S. Remote sensing monitor and driving factors of the ecological environment 
change in the source region of the Yellow River. Ecology and Environment. 17, 6, 2297-2303(2008)

8. FENG J M, WANG T, XIE C W, QI S Z. A case study on the eco-environmental degradation in the source region of the Yellow River, northeast QinghaiXizang plateau. Progress in Geography. 23, 6, 5761(2004)

9. WANG S Y, DING C B and LIU J S. Landscape evolution in the Yellow River basin using satellite remote sensing and GIS during the past decade. International journal of remote sensing. 30, 21, 55735591(2009)

10. GE J, MENG B P, YANG S X, GAO J L, YIN J P, ZHANG R P, FENG Q S, and LIANG $\mathrm{T} G$. Monitoring of above-ground biomass in alpine grassland-based on agricultural digital camera and MODIS remote sensing data: A case study in the Yellow River Headwater Region. Acta Prataculturae Sinica. 26, 7, 23-34(2017)

11. Zhang Z. Analyses of Status Quo of desert on Source of Yellow River by remote sensing information. Journal of Arid Land Resources and Environment. 14, 2, 26-28(2000)

12. FENG J M, WANG T, XIE C W, QI S Z. A Case Study on the Eco-environmental degradation in the Source Region of the Yellow River, Northeast Qinghai-Xizang Plateau. Progress in Geography, 23, 6, 57-61(2004)

13. SH W S, W H ZH, JINAG J G, XIE B. Ecological Destruction in the Source Region of the Huanghe River and Countermeasures. Rural Eco-Environment. 16, 1, 1-4(2000)

14. YANG J Z, NIE H F, JING Q Q. Analysis of mine geo-environment status and existing problems in China. Remote Sensing for Land and Resources. 29, 2, 1-7(2017) 